University of Nebraska - Lincoln

DigitalCommons@University of Nebraska - Lincoln

1955

Neascus nolfi n. sp. (Trematoda: Strigeida) from Cyprinid

Minnows with Notes on the Artificial Digest Recovery of

Helminths

Glenn L. Hoffman

US Fish and Wildlife Service

Follow this and additional works at: https://digitalcommons.unl.edu/usfwspubs

Part of the Aquaculture and Fisheries Commons

Hoffman, Glenn L., "Neascus nolfi n. sp. (Trematoda: Strigeida) from Cyprinid Minnows with Notes on the Artificial Digest Recovery of Helminths" (1955). US Fish \& Wildlife Publications. 87.

https://digitalcommons.unl.edu/usfwspubs/87

This Article is brought to you for free and open access by the US Fish \& Wildlife Service at DigitalCommons@University of Nebraska - Lincoln. It has been accepted for inclusion in US Fish \& Wildlife Publications by an authorized administrator of DigitalCommons@University of Nebraska - Lincoln. 


\title{
Neascus nolfi n. sp. (Trematoda: Strigeida) from Cyprinid Minnows with Notes on the Artificial Digest Recovery of Helminths
}

\author{
Glenn L. Hoffman \\ University of North Dakota, Grand Forks
}

During an examination of fish from Turtle River, Arvilla, North Dakota, a new Neascus (larval strigeid) was recovered from the musculature and integument of the northern creek chub, Semotilus a. atromaculatus (Mitchell) and the northern common shiner, Notropis cornutus frontalis (Agassiz). This new species is named in honor of Dr. L. O. Nolf, University of Iowa.

\section{Neascus nolfi n. sp.}

The following description is based mostly on living material except for the measurements, which were all done on metacercariae freed from their cysts, fixed in hot AFA, and stained with celestin blue B.

The outer host cyst is heavily pigmented, is nearly spherical, and ranges from 472 to $576 \mu$ in diameter. The inner thin cyst, which is probably of parasitic origin, is also nearly spherical and measures between 202 and $324 \mu$ in diameter. It cannot be separated easily from the host cyst as is the case with Uvulifer (Neascus) ambloplitis. However, the metacercaria itself of $N$. nolfi is more easily freed from the cyst with the use of small forceps and needle.

The metacercaria, which is clearly divided into fore and hind bodies, measures 290 $382 \mu$ (340 average of 4) in length and $137-153 \mu$ (147 average of 4) in greatest width. The forebody, which is thin, flat and leaf-shaped with posterior edges forming a shallow cup like most Diplostomatidae metacercariae, averages $229 \mu$ in length by $147 \mu$ in greatest width. In living worms, the great width of the forebody is very striking even while still in the cyst. The conical, rounded hindbody measures $61-107 \mu$ in length by $52-61 \mu$ in greatest width. The oral sucker is $44 \mu$ wide $\mathrm{x} 41 \mu$ long and faces anteroventrally. No prepharynx could be seen. The pharynx measures $13 \times 12 \mu$ and the esophagus is 24 to $27 \mu$ long. The intestinal crura can be seen extending into the hindbody in stained specimens but the terminations could not be ascertained; they could not be seen at all in unstained worms. The ventral sucker, which is located about mid-way in the forebody, is $17 \mu$ in diameter. The round holdfast organ is approximately $55 \mu$ in diameter.

In no instances could a reserve bladder of the excretory system be discerned; this is unusual in a Neascus. There is little likelihood that these are "young" forms of other Neascus species in which the reserve bladder system has not yet developed, because the host cyst is already pigmented. In the only black-spot Neascus which has been studied experimentally, the metacercaria is fully developed by the time the cyst becomes melanated (Hunter and Hamilton, 1941).

No evidence of reproductive fundament or holdfast gland could be discerned.

Neascus nolfi differs from: (1) Uvulifer (Neascus) ambloplitis (Hughes, 1927) in the more spherical shape and larger size of the parasite cyst, smaller size of the metacercaria, lack of reserve excretory system and intolerance of pepsin solution; (2) Crassiphiala (Neascus) bulboglossa (Van Haitsma, 1925) in the round shape and smaller size of the parasite cyst, smaller size of the metacercaria, lack of reserve excretory system, and in possession of a ventral sucker; (3) N. pyriformis Chandler (1951) in the round shape of the parasite cyst, smaller size of the metacercaria, and lack of reserve excretory system; (4) N. ellipticus Chandler (1951) in the round shape and smaller size of the parasite cyst, smaller size of the metacercaria, lack of reserve excretory system, and in possession of 
host cyst pigmentation; (5) N. rhinichthysi Hunter (1933) in the absence of a discernible reserve excretory system and the smaller size of the metacercaria.

The type specimen has been deposited in the United States National Museum Collection as No. 47898.

\section{Pepsin Digest of Fish}

Because Neascus nolfi and gasterostome metacercariae had been digested and overlooked during routine digest of fish tissue it was decided to compare three methods of isolating trematode larvae: (1) Routine pepsin digest followed by saline washings; (2) Waring blendor maceration of tissue followed by a very short pepsin digest and saline washings; (3) Waring blendor maceration followed only by saline washings.

The pepsin solution digest method of freeing encysted nematode and trematode larvae has been used by many workers and has been particularly useful in Trichinella spiralis studies. Its usefulness is great but since not all larvae can tolerate pepsin solution for very long, and some cannot tolerate it at all, it must be used with caution. Hemenway (1948), Hughes (1928c), and Wallace $(1935,1939)$ have used trypsin to assist metacercariae in excysting, and Lyster (1940) has used the plant proteolytic enzyme, papain, for liberating Trichinella spiralis larvae.

A water bath shaker was used which consists of a metal basket that fits inside the bath and is powered by a geared-down Kahn shaker. The unit makes 72 excursions per minute, and the digest bottles are held to the basket by natural rubber strips from discarded automobile inner tubes. A temperature of $39^{\circ} \mathrm{C}$ was chosen instead of $37^{\circ} \mathrm{C}$ because most of the worms recovered were those which develop to maturity in birds, and it was hoped that the $2^{\circ} \mathrm{C}$ increase would hasten digestion.

The digest solution consisted of $0.5 \%$ pepsin in $0.25 \% \mathrm{HCl}$ made up in $0.65 \%$ 3-salt Ringer's (Parker, 1938). One percent $\mathrm{HCl}$ has been used by most workers, particularly for Trichinella digest, but I hoped to minimize the possibility of acid damage to the worms. I had previously found $\mathrm{pH} 2$ and
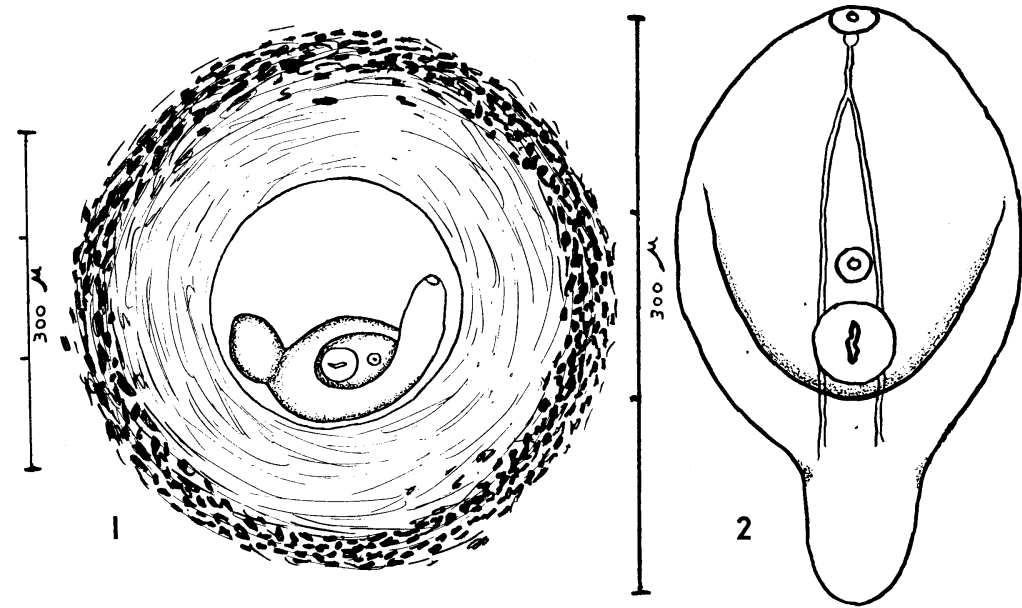

Figs. 1, 2.-1. Free hand drawing of living Neascus nolfi within the cyst.

2. Composite drawing of living, and fixed and stained Neascus nolfi. 
lower to be inimical to the survival of the metacercariae of Posthodiplostomum minimum (Hoffman, 1950). Washings were made with 0.65\% 3-salt Ringer's The digest solution was used in the approximate proportion of $20 \mathrm{cc}$ of solution to 1 gram of tissue.

Routine digestion consisted of cutting the fish into small pieces and digesting until the material appeared all digested. Rapid digestion consisted of macerating the tissue for 1 minute in the Waring blendor and then digesting for 10 to 15 minutes; this was used for muscle and integument. For viscera, the Waring blendor was omitted. The parasites were allowed to settle and the solution was decanted, followed by three or four saline washings.

Neascus nolfi was first observed after the rapid digestion technique. Although metacercariae of the common black-spot Neascus, Uvulifer ambloplitis, were alive after this treatment, none of the new metacercariae were. The cysts remained intact, however, and the gross morphology of the larvae did not appear distorted. One to 8 minutes in the Waring blendor followed by saline washing with no pepsin digest yielded a few living metacercariae which appeared normal in all respects. It was extremely difficult to macerate the tissue just enough in the Waring blendor to free large numbers of the cysts but not to damage them; consequently, only a few could be recovered alive from each infected fish. It was impossible to determine accurately the number of larvae present or the number of fish infected except that they were far less numerous than $U$. ambloplitis in the final samples. During routine pepsin digestion of fish no Neascus nolfi, gasterostome metacercariae, or cestode larvae were recovered although it was known that all were present. Only a few Posthodiplostomum minimum metacercariae survived the routine method, although the fish were heavily infected. Nematode larvae remained alive and active. Uvulifer ambloplitis metacercariae survived this treatment, and many were active and appeared uninjured, but they failed to survive when transplanted into the muscle or visceral cavity of the same species of fish. When recovered from Waring blendor washings only, both $U$. ambloplitis and $N$. nolf $i$ were alive 5 weeks after transplantation into fish of the same species.

In an attempt to free readily the intestinal nematode Rhabdochona cascadilla, and the metacercariae of Posthodiplostomum minimum, Ornithodiplostomum ptychocheilus, and other helminths present in the viscera, it was found that a 10 to 15 -minute pepsin digest in a $39^{\circ} \mathrm{C}$ water-bath shaker was satisfactory. The intestine and stomach were slit open previous to digestion. Adult Rhabdochona cascadilla, Phyllodistomum spp., and Allocreadium lobatum were recovered intact and alive and freed of all mucus. The visceral metacercariae were alive and nearly all of them were freed from their cysts. Many other workers have used a pepsin digest technique for recovering larval helminths but, to my knowledge, there is no record of others using it to free adult helminths from the mucus and mucosa. This method proved more satisfactory for recovering intestinal helminths from mucus than the $0.7 \% \mathrm{NaHCO}_{3}$ method of Bangham (1951).

The following larval trematodes have been found to survive pepsin digest methods: Amphimerus elongatus (Wallace, 1939); Apophallus venustus (Cameron, 1945); Caecincola parvulus, 2 hrs. (Lundahl, 1941); Clinostomum marginatum (Hemenway, 1948; Nolf, 1952); Diplostomulum corti (Hoffman, 1953a); Fibricola cratera, ibid; Metorchis conjunctus (Cameron, 1945); 
Ornithodiplostomum ptychocheilus (this paper); Posthodiplostomum minimum (Ferguson, 1940; Hoffman, 1950, 1953b; this paper); Sellacotyle mustelae (Wallace, 1935); Uvulifer ambloplitis (Nolf, 1952; this paper); An unidentified distome metacercariae in musculature of the brown bullhead (Hoffman, 1953a).

The following have been found not to survive pepsin digest methods: Gasterostome metacercariae, can be recovered dead after 10 min. digest (Hoffman, 1953a); Linstowiella szidati, can be recovered dead (Anderson and Cable, 1950); Neascus nolfi, can be recovered dead (this paper); an unidentified distome metacercaria in the mucosa of the creek chub can be recovered dead after $10 \mathrm{~min}$. digest (Hoffman, 1953a).

Key to the Known Larval Strigeids of North American Fish*

1. Typical strigeid constriction lacking but holdfast present; no lateral pseudo-suckers or cotylae; no ventral sucker ...................................................... 2

Typical strigeid constriction present although sometimes reduced; if no evidence of constriction there are lateral pseudo-suckers or cotylae

2. In flesh of cyprinids; cyst nearly round, about $180 \mu$; adult exp. in unfed chicks (Anderson and Cable, 1950) .........................................................

In flesh of centrarchids; possibly adult in snakes; much like L. szidati above (also a Prohemistomulum in Europe; Ciurea, 1930) (Vernberg, 1952)

Prohemistomum chandleri

3. Encysted forms

Not encysted; two lateral pseudo-suckers; hind body usually not apparent; usually in eyes, one sp. in musculature, one sp. in brain

Diplostomulum sp. and Diplostomum sp.1

a. In lens of many spp. fish; adult in gulls (Hughes and Berkhout, 1929)

Diplostomum flexicaudum

b. In musculature of Siluridae; large $(1 \mathrm{~mm})$; adults in cormorants and herons. (Ciurea, 1930; Hugghins, 1953).......(Diplosiomulum corti) Hysteromorpha triloba

c. In vitreous humor; over 3 times as long as broad (Hughes, 1929b)

Diplostomulum scheuringi

d. In optic tecti and in cyst-like structure at posterior of optic tecti of Eucalia inconstans (Hoffman, 1953; to be described later) ................. Diplostomulum sp.

e. In vitreous humor; less than 3 times as long as broad; adult in gulls Diplostomum huronense and Diplostomulum spp.2

4. Two lateral cotylae (suckers); in pericardial cavity, visceral cavity, and eye muscle; cyst nearly round; in many spp. fish .............................

Adult demonstrated in one instance in the intestine of gulls; known as Coty-

lyrus communis (Tetracotyle communis Hughes, 1928). Hughes (1928a) described 3 other sp. of Tetracotyle but because of the difficulty in identifying spp. of this genus the metacercariae are known as Tetracotyle sp. unless shown by experimentation to be metacercariae of known spp. Further life history is needed on this group.

No lateral cotylae

* The references in parentheses are not necessarily those of the original author.

1 Diplostomulum denotes larval genus where adult is unknown; perhaps is the metacercaria of Diplostomum sp.

2 If a Diplostomulum is not readily identified as one of the first 4 spp. it is designated as Diplostomulum sp. Further life history work is needed to straighten out this group. 
5. In cranial cavity of Notropis cornutus frontalis and Pimephales p. promelas; small oval cyst; adult in chick exp.; (Hoffman, 1954).... Ornithodiplostomum ptychocheilus

In viscera, mesenteries, peritoneum

In musculature and integument

6. Relatively short hindbody; constriction slight; relatively small (cyst $750 \mu$ ); in mesenteries of Cyprinidae; adult in mergansers, squaw duck, and exp. in domestic duck and unfed chick (Hughes and Piszcek, 1928; Van Haitsma, 1930; Hoffman, 1954 Ornithodiplostomum ptychocheilus

Relatively large hindbody; constriction pronounced; much larger (metacercaria over $1 \mathrm{~mm}$ ); adults in herons, exp. in unfed chicks .................... Posthodiplostomum sp.

a. In liver, kidneys and on heart of centrachids (Ferguson. 1943: Hoffman, 1950; Hughes, 1928b; Van Cleave and Mueller, 1934:249) ......P. minimum centrarchi

b. In mesenteries of cyprinids (Hughes, 1928b; Hoffman, 1950) ........P. m. minimum

c. In mesenteries of Umbra limi; forbody very large; ventral sucker in center of forebody; adult unknown (Mueller and Van Cleave, 1932:93) Neascus (Posthodiplostomum?) grandis

7. Black pigment surrounding cyst 8

No black pigment surrounding cyst .............................................................. 13

8. Metacercaria nearly fills the parasite cyst ...................................................... 9

Metacercaria does not fill the parasite cyst ........................................................ 12

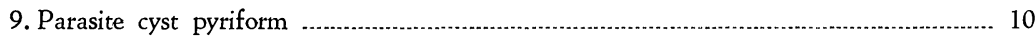

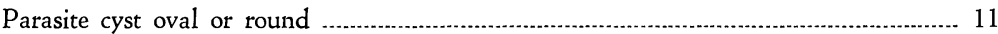

10. Parasite cyst about $330 \times 200 \mu$; in many fish; adult in kingfisher (Hughes, 1927) Unulifer (Neascus) ambloplitis

Parasite cyst smaller (about $270 \times 160 \mu$ ), abruptly narrowed at one end; in perch; adult not demonstrated, possibly is Uvulifer semicircumcisus in kingfisher. (Chandler, 1951) Neascus pyriformis

11. No ventral sucker; reserve excretory system similar to that of $N$. ambloplitis but forebody greatly cup-shaped (Hughes, 1928c) ....Crassiphiala (Neascus) bulboglossa

Ventral sucker present; reserve excretory system similar to $N$. ambloplitis although simpler; in dace; adult unknown (Hunter, Wanda, 1933) ........Neascus rhinichthysi

12. Smaller (parasite 200 to $330 \mu$ ); reserve excretory system indistinct; in Semotilus a. atromaculatus, Notropis cornutus frontalis, possibly others; adult unknown (this

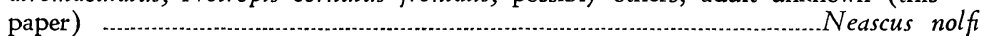

Quite large (parasite cyst $450 \mu$ long, metacercaria $870 \mu$ long); metacercaria with a finger-like anterior papilla; in perch; adult unknown (Chandler, 1951)

Neascus longicollis

13. Oral sucker smaller than ventral sucker; parasite cyst $570 \mu$ long; metacercaria $760 \mu$ long; resembles $P$. minimum somewhat; in perch; adult unknown (Chandler, 1951) Neascus ellipticus

Oral sucker larger than ventral sucker; parasite cyst about $1 \mathrm{~mm}$ long; metacercaria about $1 \frac{1}{2} \mathrm{~mm}$ long; in perch, pike, cyprinids IN EurOPE, adult in pelicans, Europe and U.S. (Ciurea, 1930; Dubois, 1938:158) ....Bolbophorus confusus

I wish to thank Dr. Asa C. Chandler, Rice Institute, Houston, Texas, for reading the manuscript and for suggestions concerning the preparation of the above key.

\section{SUMMARY}

A new strigeid metacercaria, Neascus nolf, from the creek chub, Semotilus a. atromaculatus, and shiner, Notropis cornutus frontalis, is described. 
Neascus nolfi, gasterostome metacercariae, and a distome metacercaria in the stomach mucosa of the chub do not survive pepsin digest whereas $U$ vulifer (Neascus) ambloplitis, Posthodiplostomum minimum, Ornithodiplostomum ptychocheilus, Diplostomulum corti, Fibricola cratera, and an unidentified distome metacercaria in the musculature of the bullhead do survive for varying lengths of time. The adult helminths, Phyllodistomum sp., Allocreadium lobatum, and Rhabdochona cascadilla can be freed from mucus and mucosa by 10 to 15 -minute exposure to pepsin solutions.

A key to the strigeid metacercariae of North American fish is presented.

\section{REFERENCES}

ANDerson, D. J. AND R. M. CABLE 1950-Studies on the life history of Linstowiella szidati (Anderson) (Trematoda: Strigeatoidea: Cyathocotylidae) J. Parasit. $36(5): 395-410$.

BANGHAM, R. V. 1951-Parasites in the upper Snake River drainage and in Yellowstone Lake, Wyoming. Zoologica, Sci. Contr. N. Y. Zool. Soc. 36(3):213-217.

Cameron, T. W. M. 1945-Fish-carried parasites in Canada. Canad. Jour. Comp. Med. $9: 245-254,283-286,302-311$.

Chandler, A. C. 1951-Studies on metacercariae of Perca flavescens in Lake Itasca, Minnesota. Amer. Midl. Nat. 45(3):711-721.

Ciurea, I. 1930-Contribution à l'étude morphologique et biologique de quelques strigeides des oiseaux ichtyophages de la faune de Roumanie (Recherches experimentales). Arch. Roumaines Path. Exper. et Microbiol. 3(3):277-323.

Dusors, G. 1938-Monographie des Strigeida (Trematoda). Mem. Soc. Neuchatel. Sci. Nat. V. 6, 535 pp.

FerGuson, M. S. 1940-Excystment and sterilization of metacercariae of the avian strigeid trematode, Posthodiplostomum minimum, and their development into adult worms in sterile culture. J. Parasit. 26(5):359-372.

1943-Experimental studies on the fish hosts of Posthodiplostomum minimum (Trematoda: Strigeida). Ibid. 29(5) :350-353.

Hemenway, Marilyn 1948-Studies on the excystment of Clinostomum metacercariae by use of artificial digestion. Iowa Acad. Sci. 55:375-379.

Hofrman, G. L. 1950-Studies on the development of two trematodes, Bunodera eucaliae and Posthodiplostomum minimum. Ph.D. Thesis, University of Iowa.

-1953a-Unpublished research.

1953b-Parasites of the fish of Turtle River, North Dak. Proc. N. Dak. Acad. Sci. $7: 12-19$.

1954-Notes on the occurrence of Ornithodiplostomum ptychocheilus (Faust) (Trematoda: Strigeida) in fish and birds. (Ms. submitted to J. Parasit.).

HugGhins, E. J. 1953-Life history of a strigeid trematode, Hysteromorpha triloba (Rudolphi, 1819) Lutz, 1931. J. Parasit. 39(4-2):15.

Hughes, R. C. 1927-Studies on the trematode family Strigeidae (Holostomidae). No. 6. A new metacercaria, Neascus ambloplitis, sp. nov. representing a new larval group. Trans. Amer. Micros. Soc. 46(4) :248-267.

-1928a-Idem No. 13. Three new species of Tetracotyle. Ibid. 47(4):414-433.

-1928b-Idem No. 9. Neascus vancleavei (Agersborg). Ibid. 47(3):320-341.

1928c-Idem No. 10. Neascus bulboglossa (Van Haitsma). J. Parasit. $15(1): 52-60$.

1929a-Idem No. 14. Two new species of Diplostomula. Occas. Papers Mus. Zool. Univ. Michigan (202) :1-29. 
-1929b-Idem No. 19. Diplostomulum scheuringi sp. nov. and D. vegrandis (LaRue). J. Parasit. 15(4):267-271.

ANd Berkout 1929-Idem No. 15. Diplostomulum gigas, sp. nov. Papers Michigan Acad. Sc., Arts and Letters, (1928) 10:483-488.

And F. R. Piszcek 1928-Idem No. 11. Neascus ptychocheilus (Faust). J. Parasit. 15(1):58-62.

HunTER, WANDA S. 1933-A new strigeid metacercaria, Neascus rhinichthysi, n. sp. Trans. Amer. Micros. Soc. 52(3):255-258.

G. W. Hunter III and J. M. Hamilton 1941-Studies on host-parasite reactions to larval parasites. IV. The cyst of Uvulifer ambloplitis (Hughes) Trans. Amer. Micr. Soc. 60(4) :498-507.

Lundahl, W. S. 1941-Life history of Caecincola parvulus Marshall and Gilbert (Cryptagonimidae, Trematoda) and the development of its excretory system. Ibid. $60(4): 461-484$.

LYSTER, L. L. 1940-On the use of commerrial papain for the digestion of trichinosed meat. Canad. J. of Comp. Med. 4(3):73-75.

Mueller, J. And Van Cleave 1932-Parasites of Oneida Lake fishes. Part. 2. Descriptions of new species and some general taxonomic considerations, especially concerning the trematode family Heterophyidae. Roosevelt Wild Life Ann. 3(2):73-154.

NoLF, L. O. 1952-Ms. in preparation.

PARker, R. C. 1938-Methods of tissue culture. Paul B. Hoeber, Inc. New York. 292 pp.

Van Cleave, H. J. ANd J. Mueller 1934-Parasites of Oneida Lake fishes. Part 3. A biological and ecological survey of the worm parasites. Roosevelt Wild Life Ann. 3 (3 and 4):157-373.

VAn Hartsma, J. P. 1925-Crassiphiala bulboglossa nov. gen., nov. spec., a holostomatid trematode from the belted kingfisher, Ceryle alcyon Linn. Trans. Amer. Micros. Soc. 44(3):121-131.

-1930-Studies on the trematode family Strigeidae (Holostomidae). No. 20. Paradiplostomum ptychocheilus (Faust). Ibid. 49(2):140-153.

Vernberg, Winona B. 1952-Studies on the trematode family Cyathocotylidae Poche, 1926, with the description of a new species of Holostephanus from fish and the life history of Prohemistomum chandleri sp. nov. J. Parasit. 38(4):237-340.

WALlaCE, F. G. 1935-A morphological and biological study of Sellacotyle mustelae, n. g., n. sp. Ibid. 21(3):143-166.

-1939-The metacercaria of Amphimerus elongatus Gower (Trematoda: Opisthor. chiidae). Ibid. 25(6):491-494. 